4. Кундзіч О. Л. Творчі проблеми перекладу. К.: Дніпро, 1954. 264 с.

5. Чумак Г.В. Функціонування українських реалій в англомовному постмодерному тексті роману М. Левицької «Коротка історія тракторів по-українськи». Наукові записки Тернопільського національного педагогічного університет імені Володимира Гнатюка. Серія: Літературознавство /за ред. проф. М.Ткачука. Тернопіль: ТНПУ, 2009. Вип. 26. С. 302-312.

6. Lewycka M. A Short History of Tractors in Ukrainian. London, 2006. $326 \mathrm{p}$.

DOI https://doi.org/10.30525/978-9934-26-039-1-80

\title{
ЗАСОБИ ПЕРЕКЛАДУ НЕОЛОГІЗМІВ СУЧАСНОЇ АНГЛІЙСЬКОЇ МОВИ У СФЕРІ ІНФОРМАЦІЙНИХ ТЕХНОЛОГІЙ
}

\author{
Шевчук Т. Р. \\ асистент кафедри іноземних мов \\ природничо-математичних спеціальностей \\ Волинського національного університету імені Лесі Украӥнки \\ Ясінська О. В. \\ кандидат філологічних наук, \\ доиент кафедри іноземних мов \\ природничо-математичних спеціальностей \\ Волинського національного університету імені Лесі Украӥнки \\ м. Луиькк, Україна
}

Нові технології не стоять на місці, активно продовжуючи нарощувати свою експансію. Прогресуючі процеси комп'ютеризації роблять необхідним адекватний переклад відповідних текстів з однієї мови на іншу. Складність перекладу комп’ютерної лексики полягає у тому, що більшість термінів інформаційних технологій належить до безеквівалентної лексики, але це не означає неможливість їх перекладу. В даній науковій праці нами розглядаються особливості способів перекладу неологізмів та можливі варіанти передачі неологізмів сфери інформаційних технологій з англійської мови засобами української мови.

Технічний переклад є особливим видом перекладацької діяльності, основу якої складають творчі та розумові здібності перекладача. Значна 92 
кількість помилок, що допускаються перекладачами при передачі лексики пов'язаної із інформаційними технологіями, свідчить про те, що проблема $є$ досить гострою. Пов'язані з цим проблеми розглядаються порізному, рекомендуються різні прийоми і методи перекладу, існують різні думки, оскільки однозначного, стандартного рішення тут немає. В залежності від ситуації потрібно застосовувати різні стратегії перекладу та різні перекладацькі рішення.

Процес перекладу - своєрідна мовна діяльність, спрямована на найбільш повне відтворення змісту і форми іншомовного тексту на іншій мові.

Головним прийомом перекладу будь-якого терміну для Ю. Зацного $\epsilon$ переклад за допомогою лексичного еквіваленту. Еквівалент - це постійна лексична відповідність, яка точно співпадає із значенням слова. Терміни, які мають еквівалент в українській мові, грають важливу роль при перекладі. Від них залежить розкриття значень інших слів [3]. Тому необхідно вміти знаходити відповідний еквівалент в українській мові. Для цього слід постійно збагачувати свою базу термінів-еквівалентів. Наприклад:

- keyboard - клавіатура;

- mode - режим;

- bar - панель.

Переклад безеквівалентної лексики, тобто таких слів, які позначають предмети, процеси та явища, які не мають еквівалентів на даному етапі розвитку мови, викликає значні труднощі. Наприклад:

- bum - вдосконалювати программу;

- dot-snot - самовпевнена людина, яка розбагатіла, створивши Інтернет-компанію.

Тому виділяють такі способи перекладу безеквівалентних неологізмів:

- передача неологізмів за допомогою перекладацької транслітерації та транскрипції. Спосіб транслітерації полягає у тому, що за допомогою українських букв передаються букви, 3 яких складається англійське слово. Транслітерація широко використовувалась перекладачами аж до кінця XIX століття. Для цього перекладачеві необов'язково було знати вимову англійського слова, він міг обмежитись його зоровим сприйняттям [4].

Спосіб транскрипції в перекладі полягає у передачі українськими літерами не орфографічні форми, а звучання - англійського слова. Наприклад: 
- Internet - Інтернет, chat - чат, hacker - хакер, printer - принтер, computer - комп'ютер, scanner - сканер, driver - драйвер;

- переклад неологізмів за допомогою калькування полягає в заміні складових частин, морфем чи слів (у випадку стійких словосполучень) одиниці оригіналу їх лексичними відповідниками в мові перекладу. Наприклад, слово multicurrency складається з «multi» i «currency», обидва можна перекласти окремо як «багато» та «валюта», при складанні отримуємо «багатовалютний».

Калькуванню піддаються тільки неологізми складного слова. Приклади:

- technostress - технострес, teleconsulting - телеконсультація, webbology - веббологія;

- описовий переклад використовується у випадку, якщо перекладач не може передати неологізм за допомогою раніше висвітлених прийомів. Найчастіше це трапляється тоді, коли поняття, явище, предмет, який називає неологізм відсутній в мові перекладу. Наприклад:

- cybersickness - відчуття хвороби через довге користування Інтернету.

Описовий переклад здійснюється різноманітними засобами. Поперше, це пояснювальний засіб, оскільки тут пояснюються суттєві елементи значення перекладного слова [1]. Пояснювальний переклад знаходиться ближче до тлумачення слова, але він усе ж таки залишається перекладом.

Утім навіть при оптимальному підборі пояснювального еквівалента для нього характерні такий недолік, як багатослівність. Наприклад:

- telecourse - «навчальна програма по телебаченню», teleshopping «замовлення покупки по телефону».

По-друге, прийом описового перекладу може здійснюватися підставним засобом. Підставний переклад - прийом передачі неологізму, при якому в якості його еквівалента використовується вже існуюче в мові перекладу слово (або словосполучення), яке не $\epsilon$ в ній неологізмом, але має достатню спільність значень з вихідним словом [2].

Таким чином, при перекладі неологізмів сфери IT-технологій ми застосовуємо такі засоби як еквівалент, транслітерацію і транскрипцію, калькування і описовий переклад.

\section{Література:}

1. Виноградов В.С. Введение в переводоведение (общие и лексические вопросы). Москва, 2001. 224 с. 
2. Заботкина В.И. Новая лексика современного английского языка. Москва, 1989. 280 с.

3. Зацний Ю.А. Розвиток словникового складу сучасної англійської мови: дис. ... докт. філол. наук: 10.02.04. Запоріжжя, 1998. 430 с.

4. Карабан B.I. Переклад з української мови на англійську: навч. посібник - довідник для студентів вищих закладів освіти, 2003. 608 с. 